\title{
KESADARAN HUKUM MASYARKAT TERHADAP KEPEMILIKAN E-KTP DI DUSUN BEREMBENG BARAT DESA SIGERONGAN KECAMATAN LINGSAR KABUPATEN LOMBOK BARAT
}

\author{
Ahmad Hudori' ${ }^{1)}$, Dahlan ${ }^{2)}$, M. Mabrur Haslan ${ }^{3)}$ \\ ${ }^{1}$ Mahasiswa Prodi PPKn, ${ }^{23}$ Dosen Jurusan Pendidikan IPS \\ Fakultas Keguruan dan Ilmu Pendidikan Universitas Mataram \\ Email: dahlan.01fkipgmail.com
}

\begin{abstract}
ABSTRAK
Penelitian ini adalah jenis penelitian kualitatif dengan metode deskriptif. Tujuan penelitian ini adalah untuk mengetahui kesadaran hukum masyarakat dalam kepemilikan eKTP dan faktor-faktor yang mempengaruhi kesadaran hukum masyarakat dalam kepemilikan e-KTP di Dusun Berembeng Barat Desa Sigerongan Kecamatan Lingsar Kabupaten Lombok Barat. Jumlah subjek dalam penelitian ini adalah 12 orang dan informan penelitian 5 orang dengan menggunakan teknik pengambilan sampel Purposive sampling untuk subjek penelitian dan Snowball sampling untuk informan penelitian. Teknik pengumpulan data dalam penelitian ini menggunakan metode wawancara, observasi dandokumentasi. Hasil penelitian ini menunjukan; 1)Dari jumlah total warga masyarakat dusun berembeng barat yaitu sebanyak 1.344 jiwa, didapatkan data bahwa warga yang telah membuat dan memiliki e-KTP sebanyak 576 orang yang terdiri dari 298 orang berjenis kelamin laki-laki dan 278 orang berjenis kelamin perempuan. Hal ini tentunya menunjukan kesadaran masyarakat Dusun Berembeng Barat Desa Sigerongan Kecamatan Lingar Kabuaten Lombok Barat sangat baik terhadap kepemilikan e-KTP. 2) faktor-faktor yang mempengaruhi kesadaran hukum masyarakat dalam kepemilikan e-KTP terdiri dari faktor interndan faktor ekstrn. faktor internterdiri dari Substansi Hukum(Legal Substance), dan Budaya Hukum(Legal Culture), faktor ekstrnadalah Struktur Hukum (Legal Structure).
\end{abstract}

Kata kunci: Kesadaran hukum, Kepemilikan e-KTP

\begin{abstract}
This research is a type of qualitative research with descriptive method. The purpose of this research was to determine the legal awareness of the society in the ownership of eKTP and the factors that influence public legal awareness in the ownership of e-KTP in the West Berembeng Village of Sigerongan Village, Lingsar District, West Lombok Regency. The number of subjects in this research were 12 people and 5 research informants using Purposive Sampling techniques for research subjects and Snowball Sampling for research informants. Data collection techniques in this research using the method of interview, observation and documentation. The results of this research showed; 1) Of the total number of residents of the West Berembeng Vilage, which is 1,344 people, it was found that 576 people made and owned e-KTP consisting of 298 male and 278 female. This certainly shows the awareness of the people of West Berembeng Village, Sigerongan Village, Lingar District, West Lombok Regency, about the ownership of eKTP. 2) factors that influence public legal awareness in the ownership of e-KTP consist of internal factors and extraneous factors. internal factors consist of Legal Substance, and Legal Culture, the extrn factor is the Legal Structure.
\end{abstract}

Key words: legal awareness, the ownership of e-KTP 
Vol. 6 No. 1, Oktober-Maret 2019, hh. 77-86

\section{PENDAHULUAN}

Indonesia adalah Negara hukum, hal ini dibuktikan dalam Undang-Undang Dasar Negara Republik Indonesia Tahun 1945 pasal 1 ayat (3) yang berbunyi "Negera Indonesia adalah Negara hukum". Berdasarkan konsep Negara hukum sebagaimana yang tercantum dalam UUD N RI Tahun 1945 tersebut, maka dapat dipahami bahwa di dalam kehidupan bermasyarakat, berbangsa, dan bernegara, masyarakat Indonesia diatur oleh hukum. Tak terkecuali dengan aturan yang mengatur tentang kewajiban masyarakat atau warga Negara untuk memiliki identitas kependudukan, KTP atau istilah yang sekarang dipergunakan adalah e-KTP. Hal ini termuat dalam Undang-Undang Republik Indonesia No.23 Tahun 2006 Tentang Administrasi Kependudukan Pasal 63 yang berbunyi "Penduduk warga Negara Indonesia dan orang asing yang memiliki Izin Tinggal Tetap yang telah berumur 17 (tujuh belas) tahun atau menikah atau pernah kawin wajib memiliki KTP”.

Berdasarkan pada peraturan perundang-undangan sebagaimana telah diuraikan di atas, maka dapat dipahami bahwa ada banyak aturan hukum dalam berbagai aspek kehidupan yang dibentuk untuk mengatur masyarakat Indonesia, salah satunya tentang kepemilikan KTP itu sendiri.Hal ini mengindikasikan masyarakat atau warga Negara sebagai pemeran utama dalam suatu Negara sudah sepatutnya dilandasi oleh kesadaran sebagai warga Negara yang baik yang taat terhadap atauran hukum yang berlaku. Namun disisi lain kesadaran hukum masyarakat untuk taat terhadap hukum juga masih menjadi masalah. Kesadaran hukum yang rendah cenderung pada pelanggaran hukum, sedangkan makin tinggi kesadaran hukum seseorang makin tinggi ketaatan hukumnya.

Untuk mewujudkan kesadaran hukum masyarakat terhadap hukum yang berlaku, dapat dilakukan dengan salah satu caranya yaitu membuat Kartu Tanda Penduduk (KTP).Mempunyai KTP merupakan salah satu bentuk taat pada hukum. Kartu Tanda Penduduk (KTP) adalah nama resmi kartu identitas seseorang di Indonesia yang diperoleh setelah seseorang berusia di atas 17 tahun. KTP berlaku selama lima tahun dan tanggal berakhirnya disesuaikan dengan tanggal dan bulan kelahiran seseorang yang bersangkutan. Khusus warga Negara yang berusia 60 tahun ke atas, mendapat KTP yang berlaku seumur hidup sehingga tidak perlu untuk diperpanjang dalam rentan waktu lima tahun sekali (Satiana, 2013: 20).

Berakhirnya masa berlaku KTP, sesuai dengan tanggal dan bulan kelahiran yang bersangkutan. Apabila KTP yang rusak, hilang, atau berubah data, seperti alamat, kewarganegaraan, nama dan sebagainya harus diganti dengan KTP yang baru. Yang tidak wajib memiliki KTP adalah anggota perwakilan asing, Organisasi-organisasi Internasional, Corps Diplomatik beserta anggota keluarganya dan penduduk sementara.

Pada Februari 2011 Kementerian Dalam Negeri Republik Indonesia (Kemendagri RI) meluncurkan program e-KTP.KTP yang pada awalnya dalam bentuk konvensional mempunyai rentan waktu atau masa berlakunya, tapi tidak demikian dengan e-KTP yang masa berlakunya seumur hidup. Jadi tidak perlu untuk diperbaharui masa berlakunya dalam kurun waktu lima tahun sekali (Artini, 2016). Program e-KTP 
dilatarbelakangi oleh sistem pembuatan KTP konvensional di Indonesia yang memungkinkan seseorang dapat memiliki lebih dari satu KTP. Hal ini disebabkan belum adanya basis data terpadu yang menghimpun data penduduk dari seluruh Indonesia. Fakta tersebut memberi peluang penduduk yang ingin berbuat curang terhadap negara dengan menduplikasi KTP-nya.Untuk mengatasi duplikasi tersebut sekaligus menciptakan kartu identitas multifungsi, digagaslah e-KTP yang menggunakan pengamanan berbasis biometrik.

E-KTP atau elektronik-KTP adalah dokumen kependudukan yang memuat sistem keamanan atau pengendalian baik dari sisi administrasi ataupun teknologi informasi dengan berbasis pada data base kependudukan nasional. Penduduk hanya diperbolehkan memiliki 1 (satu) KTP yang tercantum Nomor Induk Kependudukan (NIK). NIK merupakan identitas tunggal setiap penduduk dan berlaku seumur hidup. Nomor NIK yang ada di KTP e-KTP nantinya akan dijadikan dasar dalam penerbitan Paspor, Surat Izin Mengemudi (SIM), Nomor Pokok Wajib Pajak (NPWP), Polis Asuransi, Sertifikat atas Hak Tanah dan penerbitan dokumen identitas lainnya (Pasal 13 UU No. 23 Tahun 2006 tentang Adminduk).

Mengacu pada Peraturan Daerah Kabupaten Lombok Barat Nomor 6 Tahun 2008 tentang Penyelenggaran Pendaftaran Penduduk dan Pencatatan Sipil (Lembaran Daerah Kabupaten Lombok Barat tahun 2008), Peraturan Daerah Kabupaten Lombok Barat Nomor 11 Tahun 2015 tentang Penyelenggaran Administrasi Kependudukan, pernyataan tegas tercantum dalam peraturan Negara Indonesia, akan tetapi melihat realita yang terjadi di Negara Indonesia yang rawan terjadi musibah, bukan musibah yang dikarenakan oleh bencana alam saja, laju pertumbuhan ekonomi di masing-masing daerah yang berbedabeda, tingkat pengetahun atau sumber daya manusianya yang dapat mempengaruhi tingkat kesadaran hukum masyarakat. Seperti yang tercermin dalam permasalahan masyarakat yang tidak mempunyai e-KTP.

Dalam kehidupan masyarakat yang tidak sadar akan pentingnya kepemilikan Kartu Tanda Penduduk, dipengaruhi oleh dua faktor, yaitu faktor intern dan faktor ektern. Faktor intern yang mempengaruhi masyarakat tidak sadar hukum itu datang dari dalam diri pribadi seseorang seperti masyarakat yang melalaikan kepemilikan KTP dipengaruhi oleh ketidaktahuan dan ketidakpahaman akan keberadaan hukum yang mengaturnya. Sedangkan faktor ektern yang mempengaruhi masyarakat tidak sadar hukum yaitu berasal dari pihak luar dari pribadi itu sendiri yang mempengaruhi tingkat kesadaran hukum masyarakat terhadap hukum. Hal tersebut mempengaruhi tingkat kesadaran dalam kepemilikan KTP, karena selain masyarakat tidak mengetahui dan memahami keberadaan hukum, yang menjadi faktor utama masyarakat tidak memiliki KTP yaitu adalah prosesnya yang rumit, berbelit-belit dan biaya pembuatan KTP yang tidak sesuai dengan peraturan. Padahal untuk menumbuhkan kesadaran setiap warga masyarakat itu tidak hanya dari diri sendiri masyarakat saja, melainkan petugas atau aparatur yang terlibat dan bertugas dalam pembuatan KTP tersebut.

Oleh karena itu, akibat dari kurangnya kerjasama antara masyarakat desa dan petugas pengelola pembuat KTP tersebut. Masyarakat desa bukan saja tidak sadar akan hukum dan kewajibannya, akan tapi mereka tidak mengetahui dan memahami tentang kewajiban itu, akibatnya tidak sedikit masyarakat yang melalaikan kepemilikan KTP tersebut. Padahal kepemilikan KTP itu telah memiliki kepastian dan kekuatan 
Vol. 6 No. 1, Oktober-Maret 2019, hh. 77-86

hukum yang apabila melanggar mendapatkan sangksi atau hukuman.Sangksi atau hukuman yang diterima oleh warga masyarakat yang tidak mempunyai KTP adalah sanksi administratif.Sanksi administrasi dalam bentuk penonaktifan KTP ini akan membuat penduduk tidak mendapatkan pelayanan publik.Contohnya, BPJS, itu kan basisnya Nomor Induk Kependudukan (NIK), kemudian membuka kartu perdana itu basisnya NIK. Jika NIK tidak muncul, maka haknya sebagai penduduk Indonesia tidak akan bisa dipenuhi (Liputan6.com, 23/8/2016).

Berdasarkan uraian diatas, dapat dipahami bahwa sangatlah penting untuk memiliki Kartu Tanda Penduduk itu sendiri jika melihat fungsi dan kegunaan dari KTP itu sendiri yang sangat mendasar seperti saat anggota masyarakat hendak menikah maka dibutuhkan KTP untuk mendaftarkan pernikahan tersebut ke Kantor Urusan Agama. Demikian juga halnya apabila masyarakat Indonesia termasuk warga Dusun Berembeng Barat ingin melamar pekerjaan KTP adalah salah satu persyaratan yang diminta oleh instansi atau lembaga yang menyediakan lapangan pekerjaan kepada calon pegawainnya.

Melihat kondisi di atas, berdasarkan studi pendahuluan yang peneliti lakukan pada Selasa 1 Mei dan Minggu 6 Mei 2018 di Dusun Berembeng Barat Desa Sigerongan Kecamatan Lingsar Kabupaten Lombok Barat, ditemukan masih adanya masyarakat yang belum sadar atau menyadari akan pentingnya kepemilikan KTP itu sendiri. Masyarakat yang belum sadar tersebut beranekaragam golongan, mulai dari pemula atau siswa usia sekolah yang sudah mengijak usia 17 (tujuh belas) tahun, pemuda hingga orang tua dan lanjut usia (lansia). Kondisi tersebut dipengaruhi oleh ketidaksadaran masyarakat akan pentingnya kepemilikan KTP, faktor ketidaktahuan tentang tata cara pengurusan untuk membuat KTP atau masih beranggapan bahwa proses pembuatan KTP tersebut sulit dan rumit, faktor pendidikan, serta waktu yang sangat lama, serta faktor kepercayaan masyarakat terhadap aparatur terkait atau pemerintah semenjak terjadinya kasus korupsi e-KTP.

Berdasarkan uraian latar belakang diatas, maka dapat dirumuskan permasalahan dalam peneltian ini adalah: 1) Bagaimanakah kesadaran hukum masyarakat terhadap kepemilikan e-KTP di Dusun Berembeng Barat Desa Sigerongan Kecamatan Lingsar Kabupaten Lombok Barat?; 2) Faktor-faktor yang mempengaruhi kesadaran hukum masyarakat terhadap kepemilikan e-KTP di Dusun Berembeng Barat Desa Sigerongan Kecamatan Lingsar Kabupaten Lombok Barat?Kemudian dari rumusan masalah tersebut maka dapat diketahui tujuan dari penelitian ini adalah: (1) Untuk mengetahui kesadaran hukum masyarakat terhadap kepemilikan e-KTP di Dusun Berembeng Barat Desa Sigerongan Kecamatan Lingsar Kabupaten Lombok Barat; (2) Untuk mengetahui Faktor-faktor yang mempengaruhi kesadaran hukum masyarakat terhadap kepemilikan e-KTP di Dusun Berembeng Barat Desa Sigerongan Kecamatan Lingsar Kabupaten Lombok Barat.

\section{METODE PENELITIAN}

Penelitian ini menggunakan penedekatan kualitatif dengan metode deskriptif, karena penelitian ini akan mendeskripsikan atau menggambarkan secara mendalam tentang kesadaran hukum masyarakat terhadap 
kepemilikan e-KTP di Dusun Berembeng Barat Desa Sigerongan Kecamatan Lingsar. Penelitian ini telah dilaksanakan mulai bulan September-November 2018.

Subyek dalam penelitian ini adalah masyarakat yang berdomisili di Dusun Berembeng Barat. Subyek peneltian ditentukan dengan menggunakan purposive sampling, dengan pertimbangan-pertimbangan, sebagai berikut: 1) Warga Negara Indonesia; 2) Masyarakat asli Dusun Berembeng Barat Desa Sigerongan Kecamatan Lingsar Kabupaten Lombok Barat; 3) Sudah berusia 17 (tujuh belas) tahun atau sudah menikah; 4) Berada dalam kondisi kejiwaan yang waras (tidak gila).

Informan dalam penelitian ini adalah Kepala Desa Sigerongan, Staf Desa Sigerongan yang menangani pembuatan e-KTP, Kepala Dusun Berembeng Barat, RT RT 05, dan RT 08orang yang diperkirakan menguasai dan memahami data, informasi ataupun fakta dari suatu objek penelitian. Informan ditentukan menggunakan Snowball sampling.

Teknik pengumpulan data adalah cara-cara yang digunakan peneliti untuk mengumpulkan data. Adapun tehnik pengumpulan data yang digunakan oleh peneliti adalah: Teknik wawancara menurut Abdurrahman (2009: 114) merupakan suatu proses interakasi dan komunikasi. Wawancara dalam penelitian ini dilakukan untuk mendapatkan informasi dengan cara wawancara langsung dengan informan, menggunakan pedoman wawancara yang telah disusun sebelumnya. Teknik observasi menurut Bugin (2007: 115) adalah metode pengumpulan data yang digunakan untuk penghimpunan data penelitian melalui pengamatan dan pengindraan. Selain itu Arikunto (2002: 206) mengemukakan bahwa peneliti dalam melaksanakan metode dokumentasi, peneliti menyelidiki benda-benda tertulis seperti buku-buku, majalah, dokumen, peraturan-peraturan, notulen, catatan harian, dan sebagainya.

Adapun langkah-langkah dalam analisis data menurut Miles danHuberman(1992: 12-13) yaitu: Reduksi data (data reduction) merupakan tahap merangkum, memilih hal-hal pokok, memfokuskan pada hal-hal yang penting, dicarai tema dan polanya, bertujuan memberikan gambaran yang jelas dan mempermudah penelti untuk melakukan pengumpulan data. Selanjutnya dilakukan penyajian data (data display) melalaui uraian singkat, bagan, hubungan antar kategori, flowchartsehingga akan semakin mudah dipahami. Langkah yang terakhir penarikan kesimpulan (conlusion drawing) dapat berupa deskripsi atau gambaran suatu obyek yang sebelumnya masih remang-remang atau gelap sehingga setelah diteliti menjadi jelas, dapat berupa hubungan kasual atau interaktif, hipotesis atau teori.

\section{HASIL PENELITIAN}

\section{Kesadaran Hukum Masyarakat Terhadap Kepemilikan e-KTP di Dusun Berembeng Barat Desa Sigerongan Kecamatan Lingsar Kabupaten Lombok Barat}

Dari hasil wawancara yang dilakukan peneliti dengan Bapak Haris Fathul, yang di wawancarai mengenai kesadaran masyarakat terhadap kepemilikan e-KTP, beliau menuturkan:“...saya rasa semua sudah sadar, hal ini terbukti pada waktu pembuatan e-KTP masyarakat berbondong-bondong pergi ke kantor desa 
Vol. 6 No. 1, Oktober-Maret 2019, hh. 77-86

untuk melakukan perekaman...”. Selanjutnyabapak H. Muhmmad Sutriawan, S.pd.i yang juga selaku Kepala Desa Sigerongan, beliau menuturkan bagaimana kesadaran masyarakat Dusun Berembeng Barat Desa Sigerongan terhadap kepemilikan e-KTP, berikut penuturannya:““...masyarakat sudah sadar, hal ini terbukti dengan banyaknya masyarakat yang dating untuk meminta perekaman untuk pembuatan e-KTP serta banyaknya kebutuhan masyarakat yang dipersyaratkan dengan e-KTP...”

Faktor-faktor yang Mempengaruhi Kesadaran Hukum Masyarakat Terhadap Kepemilikan e-KTP di Dusun Berembeng Barat Desa Sigerongan Kecamatan Lingsar Kabupaten Lombok Barat

1. Isi Hukum (Legal Substance)

Berdasarkan hasil wawancara yang dilakukan terkait dengan pengetahuan masyarakat akan kewajiban masyarakat untuk memilki e-KTP, subjek penelitian mengungkapkan:Subjek 01“...wajib, karena e-KTP menunjukan identitas pribadi dan masyarakat...”. Selanjutnya Informan 01 “...Iya wajib, karena untuk menujukan identitas pribadi atau pengenalan seseorang...”(wawancara peneliti dengan informan 01, 01 Oktober 2018).

2. Struktur Hukum (Legal Structure)

Berdasarkan hasil wawancara yang dilakukan terkait dengan siapa saja aktor yang terdapat di Desa atau Dusun ini, sudah atau tidaknya penegak hukum bekerja secara optimal khususnya dalam pembuatan e-KTP dan dan apakah para penegak hukum terkait pernah atau belum melakukan pendataan terhadap warganya tentang kepemilikan e-KTP, subjek penelitian mengungkapkan: Subjek 01 “...Kepala Dusun, Ketua RT, Kiyai, Penghulu, Tokoh Masyarakat, Tokoh Adat...”. Selanjutnya Informan 01 “...Kepala Dusun, Tokoh Agama, Tokoh Masyarakat, Tokoh Adat, dan Aparat lainya Seperti Kepala Desa, Sekretaris Desa, Babinsa, Babinmaspol...”.

3. Budaya Hukum (Legal Culture)

Berdasarkan hasil wawancara yang dilakukan peneliti dengan subjek penelitian terkait dengan ketanggapan (sikap) atau acuh (tidak peduli) masyarakat apabila sudah tiba waktu pembuatan e-KTP, berikut hasilnya: Subjek 01 “...tanggap, karena kalau KTP mati atau sudah tidak berlaku segala urusan akan susah atau terkendala...”. Selanjutnya Informan 03 “...Sangat tanggap, masyarakat tanggap ketika informasi sudah diumumkan...”.

\section{PEMBAHASAN}

Kesadaran Hukum Masyarakat Terhadap Kepemilikan e-KTP di Dusun Berembeng Barat Desa Sigerongan Kecamatan Lingsar Kabupaten Lombok Barat Tolong Menolong

Dari jumlah total warga masyarakat dusun berembeng barat yaitu sebanyak 1.344 jiwa, didapatkan data bahwa warga yang telah membuat dan memiliki e-KTP sebanyak 576 orang yang terdiri dari 298 orang berjenis kelamin laki-laki dan 278 orang berjenis kelamin perempuan. Hal ini tentunya menunjukan 
kesadaran masyarakat Dusun Berembeng Barat Desa Sigerongan Kecamatan Lingar Kabupaten Lombok Barat sangat baik terhadap kepemilikan e-KTP.

Jika melihat dari pengertian kesadaran hukum, menurut Abdurrahman (Budiana, 2014: 14), kesadaran hukum adalah suatu kesadaran yang ada dalam kehidupan manusia untuk selalu patuh dan taat pada hukum. Sedangkan, Menurut Soerjono Soekanto (1982) Kesadaran hukum sebenarnya adalah kesadaran atau nilainilai yang terdapat dalam diri manusia tentang hukum yang ada atau tentang hukum yang diharapkan (http://www.bhataramedia.com/forum/apa-pengertian-kesadaran-hukum-menurut-para-ahli/: diakses 8 juli 2018). Hal ini jelas menggambarkan kesadaran hukum masyarakat Dusun Berembeng Barat terhadap kepemilikan e-KTP yang didasarkan pada nilai-nilai yang ada dalam diri masyarakat itu sendiri untuk senantiasa taat dan patuh terhadap hukum yang berlaku.

Secara tidak langsung masyarakat mengetahui bahwa ada hukum yang mengatur mereka dalam kehidupan berbangsa dan bernegara khusunya dalam hal kepemilikan e-KTP. Kesadaran hukum mesyarakat itu tentunya timbul akibat dari suatu pengetahuan dan pemahaman terhadap hukum itu sendiri.Kesadaran hukum yang rendah cenderung pada pelanggaran hukum, sedangkan makin tinggi kesadaran hukum seseorang makin tinggi ketaatan hukumnya.

Dengan demikian kesadaran hukum yang ditunjukan oleh masyarakat adalah sikap dan perilaku yang wajar oleh seseorang (manusia) secara umum, sebagai bentuk kesadaran pada adanya pemahaman terhadap hukum, yang didasarkan karena adanya hak dan kepentingan manusia tentang apa arti dan seharusnya hukum itu, dan bagaimana mematuhi maupun mentaati hukum tanpa harus ada unsur paksaan.

\section{Faktor-faktor yang Mempengaruhi Kesadaran Hukum Masyarakat Terhadap Kepemilikan e-KTP di Dusun Berembeng Barat Desa Sigerongan Kecamatan Lingsar Kabupaten Lombok Barat}

Pertama Faktor intern,Substansi Hukum(Legal Substance)Lawrence Meir Friedman menyesebut ini sebagai sistem substansial yangmenentukan bisa atau tidaknya hukum itu dilaksanakan. Substansi juga berarti produk yangdihasilkan oleh orang yang berada dalam sistem hukum yang mencakup keputusan yang mereka keluarkan, aturan baru yang mereka susun. Berkaitan dengan aturan, identitas kependudukan telah diatur dalam peraturan perundang-udangan di Republik Indonesia yang termuat dalam Undang-Undang Republik Indonesia No.23 Tahun 2006 Tentang Administrasi Kependudukan Pasal 63 yang berbunyi "Penduduk warga Negara Indonesia dan orang asing yang memiliki Izin Tinggal Tetap yang telah berumur 17 (tujuh belas) tahun atau menikah atau pernah kawin wajib memiliki KTP”.

Dari aturan tersebut diatas jelas menyebutkan bahwa memiliki e-KTP adalah suatu kewajiban bagi masyarakat Indonesia, dan hal inilah yang terjadi atau ditemukan di masyarakat Dusun Berembeng Barat Desa Sigerongan Kecamatan Lingsar Kabupaten Lombok Barat dimana kesadaran masyarakat untuk 
Vol. 6 No. 1, Oktober-Maret 2019, hh. 77-86

memiliki e-KTP didasarkan pada nilai-nilai yang ada dalam diri mereka terhadap suatu aturan yang substansinya mewajibkan mereka untuk memilikinya.

Faktor intern kedua, Budaya Hukum(Legal Culture) Kultur hukum menurut LawrenceMeir Friedman (2001:8) adalah sikap manusia terhadap hukum dan sistem hukum-kepercayaan,nilai, pemikiran, serta harapannya. Kultur hukum adalah suasana pemikiran sosial dan kekuatansosial yang menentukan bagaimana hukum digunakan, dihindari, atau disalahgunakan. Budayahukum erat kaitannya dengan kesadaran hukum masyarakat. Semakin tinggi kesadaran hukummasyarakat maka akan tercipta budaya hukum yang baik dan dapat merubah pola pikir masyarakat mengenai hukum selama ini.

Berdasarkan hasil penelitian yang sudah dilakukan baik melalui metode wawancara, observasi dan dokumentasi menunjukan sikap dan perilaku masyarakat yang respect (peduli) atau taat terhadap aturan yang berlaku khusunya dalam kepemilikan e-KTP. Dimana data hasil penelitian menujukan kesadaran hukum masyarakat Dusun Berembeng Barat yang tinggi sehingga mendorong masyarakat untuk membuat atau memiliki e-KTP.

Hal ini terbukti bahwa ketika Kepala Dusun sudah menyampaikan atau mensosialisasikan terkait dengan e-KTP mulai dari proses pembuatannya, waktu pembuatan, sampai dengan syarat-syarat yang harus dipenuhi masyarakat menyambut dan merespon dengan baik informasi yang sudah disampaikan dan langsung berbondong-bondong untuk mengurus dan membuat e-KTP ke Kantor Desa Sigerongan dan Kantor Camat Lingsar.

Data hasil penelitian membuktikan mentailtas aktor penegak hukum yang terdapat di Dusun Berembeng Barat khususnya dalam pembuatan e-KTP baik atau kuat, sebab jika mentalitas aparat penegak hukum itu sendiri lemah maka akan mengakibatkan penegakkan hukum tidak berjalansebagaimana mestinya.Dengan adanya aktor penegak hukum yang bekerja secara maksimal ditengah-tengah masyarakat tentunya akan menumbuhkan dan meningkatkan kesadaran masyarakat untuk senantiasa taat dan patuh terhadap hukum yang berlaku khususnya terkait dengan kepemilikan e-KTP. Sehingga dapat dipertegas bahwa faktor penegak hukum memainkan peran penting dalam memfungsikan hukum.

\section{PENUTUP}

\section{Simpulan}

1. Bagaimanakah Kesadaran Hukum Masyarakat Terhadap Kepemilikan e-KTP di Dusun Berembeng Barat Desa Sigerongan Kecamatan Lingsar Kabupaten Lombok Barat: Dari jumlah total warga masyarakat dusun berembeng barat yaitu sebanyak 1.344 jiwa, didapatkan data bahwa warga yang telah membuat dan memiliki e-KTP sebanyak 576 orang yang terdiri dari 298 orang berjenis kelamin laki-laki dan 278 orang berjenis kelamin perempuan. Hal ini tentunya menunjukan kesadaran masyarakat Dusun Berembeng Barat Desa Sigerongan Kecamatan Lingar Kabupaten Lombok Barat sangat baik terhadap kepemilikan e-KTP. 
2. Faktor-faktor yang Mempengaruhi Kesadaran Hukum Masyarakat Terhadap Kepemilikan e-KTP di Dusun Berembeng Barat Desa Sigerongan Kecamatan Lingsar Kabupaten Lombok Barat: Menurut Lawrence Meir Friedman berhasil atau tidaknya Penegakan hukum bergantung pada: Substansi Hukum (Legal Substance), Struktur Hukum atau Pranata Hukum (Legal Structure) dan Budaya Hukum (Legal Culture). Yang dimana ketiga hal tersebut dapat dikategorikan ke dalam dua faktor yang mempengaruhi kesadaran hukum masyarakat yaitu faktor intern adalah Substansi Hukum (Legal Substance), dan Budaya Hukum (Legal Culture), faktor ekstrn adalah Struktur Hukum (Legal Structure).

\section{Saran}

1. Seluruh warga di Dusun Berembeng Barat Desa Sigerongan Kecamatan Lingsar dapat mempertahankan dan meningkatkan kesadaran hukumnya terhadap hukum yang berlaku khusunya dalam kepemilikan eKTP.

2. Seluruh steakholder yang ada baik itu di tingkat Dusun ataupun Desa untuk saling bersatu padu untuk meningkatkan kesadaran hukum masyarakat dengan konsisten untuk melakukan penyuluhan dan kampanye kesadaran hukum kepada masyarakat.

3. Antar warga masyarakat selalu saling mengingatkan dan mawas diri untuk selalu taat terhadap aturan hukum yang berlaku khususnya terkait dengan kepemilikan e-KTP.

\section{DAFTAR PUSTAKA}

Abdurrahman, Muslan. 2009. Sosiologi dan Metode Penelitian Hukum. Malang: UMM Press.

Anggraini, Ririn. Kesadaran Hukum Pengguna Kendaraan Bermotor Roda Dua Dalam Berlalu Lintas. Skripsi tidak diterbitkan. Mataram: Program Sarjana Universitas Mataram.

Arikunto, S. 2013. Manajemen Penelitian. Jakarta: Rineka Cipta.

Arikunto, S. 2013. Manajemen Penelitian. Jakarta: Rineka Cipta.

Arikunto, Suharsimi. 2002. Metodologi Penelitian. Jakarta: PT. Rineka Cipta.

Asyhadie dkk. 2013. Pengantar Ilmu Hukum. Jakarta. PT Raja Grafindo Persada

Budiana, Irwan. Kesadaran Hukum Pedagang Kaki Lima Dalam Menjaga Kebersihan, Keindahan dan Ketertiban. Skripsi tidak diterbitkan. Mataram: Program Sarjana Universitas Mataram.

Bungin, Burhan H. M. 2007. Penelitian Kualitatif. Jakarta: Kencana Prenama Media Group.

Miles. B Matthew dan Huberman, A Michael, 1992. Analisis Data Kualitatif. Jakarta: Universitas Indonesia Press.

Moleong, Lexy, J. 2005. Metodologi Penelitian Kualitatif Edizi Revisi. Bandung: PT Remaja Rosdakarya Offset.

Sugiyono. 2015. Metode Penelitian Pendidikan: Pendekatan Kuantitatif, Kualitatif, dan R\&D. Bandung: Alfabeta. 
Vol. 6 No. 1, Oktober-Maret 2019, hh. 77-86

Sutiana, Angger. Kesadaran Hukum Warga Negara Terhadap Kepemilikan Kartu Tanda Penduduk Di Kota Pati. Semarang. Jurnal Ilmiah PPKn IKIP VETERAN SEMARANG

\section{Situs Online :}

Artikel Probo Pribadi: http://probopribadisembiringmeliala.blogspot.com/2016/03/meningkatkan-kesadaranhukum-di.html : di akses, jumat 30 agustus 2018

Artikel Sudikno : http://sudiknoartikel.blogspot.com/2008/03/meningkatkan-kesadaran-hukummasyarakat.html : diaskes tanggal 31 Mei 2018

Baca Madani : http://www.bacaanmadani.com/2017/09/pengertian-kepemilikan-milkiyah-sebab.html : diaskses tanggal 8 Mei 2018.

Bhatara Media : http://www.bhataramedia.com/forum/apa-pengertian-kesadaran-hukum-menurut-para-ahli/) : diakses tanggal 8 juli 2018.

http://be-es-i.blogspot.co.id/2012/01/pengertian-e-ktp-ktp-elektronik.html : diakses tanggal 18 Mei 2018

http://usmanunram.blogspot.com/2015/01/kesadaran-hukum.html : diakses jumat, 30 agustus 2018

https://manfaat.co.id/manfaat-ktp : diakses tanggal 18 Mei 2018

Liputan6.com : https://www.liputan6.com/news/read/2583766/ini-sanksi-bila-tak-bikin-e-ktp-sebelum-30september-2016 : diakses tanggal 18 Mei 2018 